\title{
Modeling the Factors of Productivity in Airline Industry in India: A Hybrid TISM-P and Fuzzy-MICMAC Approach
}

\author{
Shamita Garg ${ }^{1}$ (D) Vikas Thakur ${ }^{2}$
}

Received: 29 January 2021 / Accepted: 29 July 2021 / Published online: 24 August 2021

(c) Global Institute of Flexible Systems Management 2021

\begin{abstract}
The present study explores the productivity drivers of the airline industry in India for their national and international performance. Interpretive structural modeling with polarity (TISM-P) approach is opted for exploring the interrelationships among productivity drivers of the airline industry by considering the experts' inputs. The study identified 17 factors driving the productivity of the airline industry, and experts' inputs had placed them in nine levels using a TISM-P approach. Fuzzy-MICMAC (Matrice d'impacts croisés multiplication appliquée á un classment) analysis further has classified these 17 factors into the following four groups: autonomous, dependent, linkage, and independent group. Also, it is observed that refining productivity issues have increased the airline industry's export performance. The airlines' administration can plan the short-term objectives by considering the independent factors and long-term policies by focussing on the linkage and dependent factors for improving the overall productivity and export performance.
\end{abstract}

Keywords Productivity $\cdot$ Operational excellence $\cdot$ Service competitiveness $\cdot$ Airline industry $\cdot$ TISM-P $\cdot$ Fuzzy-MICMAC

\section{Introduction}

With the opening up of the skies by the Indian Government, the aviation industry has undergone a rapid transformation. Srivastava and Chaurasia (2015) proclaim that previously, the Indian aviation sector was primarily a governmentowned industry, but now it is dominated by most of the private players. With the intense competition in the aviation industry, airlines need to improve their performance to sustain themselves in the market for a long time. The exports and financial performance of the airline industry in India in the last decade have been highlighted in Table A1, (given in supplementary file). Barbot et al. (2008), and Arulraj and Annamalai (2020) assert that productivity has been the central importance of competitiveness and world prosperity since the beginning of industrialization, but describing

Shamita Garg

shmita.garg89@gmail.com

Vikas Thakur

ervikythakur@gmail.com

1 Department of Management Studies, Indian Institute of Technology, Delhi, New Delhi, India

2 School of Management, National Institute of Technology, Rourkela, Odisha, India the specific industry's productivity function is challenging (Arulraj \& Annamalai 2020). Pekuri et al. (2011) have identified productivity as a critical driver for measuring an organization's performance. In the contemporary turbulent business situation, firm operational excellence has become of utmost significance for gaining international competitiveness (Gelmez et al., 2020). Sushil and Garg (2019) state that export performance could be used as a surrogate measure for international competitiveness. Vasigh and Fleming (2005) have analyzed airlines' efficiency and effectiveness through the total factor productivity (TFP) method-based utilization of input resources.

Though a lot of work has been conducted on airlines' productivity, but very few have tried to develop a relationship between the factors associated with airlines' productivity and competitiveness. Moreover, the recent hit by the COVID-19 outbreak has made the situation worst for the aviation sector, where most of the routes have been either cancelled off or operating with limited capacity. Hence, the operational competitiveness of the airline industry in India needs thorough revision and pinpoints the main productivity drivers to enhance the overall performance (Arulraj \& Annamalai, 2020). The present work has attempted to fulfil that void by modelling the selected factors related to airlines' productivity. This model would help airlines' administration 
Table 1 Factors affecting the productivity of the airline industry

\begin{tabular}{|c|c|}
\hline Factor & Description \\
\hline Business model & $\begin{array}{l}\text { Many new airlines emerging in the market have } \\
\text { adopted low-cost models. A low-cost carrier mode } \\
\text { allows faster decision-making in an emergency }\end{array}$ \\
\hline Outsourcing & $\begin{array}{l}\text { Most airlines outsourced their non-core activities } \\
\text { like maintenance, food services, baggage handling, } \\
\text { aircraft interior handling, pilot training, and adver- } \\
\text { tising to reduce the operational cost for the airline } \\
\text { industry }\end{array}$ \\
\hline Ownership and control & $\begin{array}{l}\text { Ownership and control are perennial subjects for } \\
\text { the operational excellence of any airline. Privately } \\
\text { owned airlines have a greater degree of autonomy } \\
\text { while making decisions than public ownership in } \\
\text { airlines }\end{array}$ \\
\hline
\end{tabular}

Training programs

Quality of process

Technological advancement

Labour unions

Alliance

Resource allocation

Operating cost

Maintenance

Network structure

Frequency of service

Available seat mile (K.M.)

Distribution channel

Frequent traveling schemes

Revenue passenger mile (RPM)
Regular training programs improve operational excellence

Quality of process has a positive influence on the operational excellence of an airline

Technology advancement significantly influences the airlines' unit cost, fleet characteristics, miles flown, stage length, operation pattern, and aircraft utilization

Proactive management could build a strong relationship between employees and management

Co-operation/coordination among airlines provide better services to customers

The more effectively an airline utilizes its resources, the more productive it becomes

Operating cost is the cost of resources that any organization uses to maintain its existence

Maintenance programs keep the aircraft in flying conditions and minimize aircraft on ground time

Route structure is one of the critical factors affecting airlines' performance. As a result, Hub and spoke networks have improved connectivity to smaller markets and routes

The frequency of flights depends upon the market demographics, airline characteristics, airport characteristics, and route characteristics. Consequently, the fleet and operating frequency services significantly impact airlines' operational excellence

While interacting with airline veterans, it has been found that 'Available Seat miles' or 'kilometers' is the primary measure of capacity

An integrated approach for channel distribution into revenue management could improve airlines' earnings

Frequent traveling bonus schemes like the scheme based on the number of trips to be taken instead of mileage accumulation have helped develop loyalty among passengers towards airlines

The DEA index computation revealed that output could be measured through revenue output measures (passenger-kilometers and freight tonne-kilometers. Revenue passenger mile (RPM) is an essential measure of production
Source

Fu et al. (2019), Khuong and Uyen (2014)

Ashraf et al. (2013), Murty et al. (2013)

Suhardjanto and Ajibroto (2017), Ashraf et al. (2013)

Khuong and Uyen (2014), Ratanakomaut and Kitcharoen (2013)

Ratanakomut and Kitcharoen (2013), Knorr and Arndt (2002)

Eller and Moreira (2013), Ratanakomaut and Kitcharoen (2013)

Ashraf et al. (2013), Knorr and Arndt (2002)

Chiambaretto and Wassmer (2019), Lazzarini (2007)

Vasigh and Fleming (2005), Knorr and Arndt (2002)

Swidan and Merkert (2019), Knorr and Arndt (2002)

Chang and Yeh (2004), Sriram \& Haghani, 2003

Eller and Moreira (2013), Vasigh and Fleming (2005)

Wei and Hansen (2007), Knorr and Arndt (2002)

May and Barry (2011), Wei and Hansen (2005)

Wang et al. (2018), Knorr and Arndt (2002)

Knorr and Arndt (2002)

Oum et al. (1999) 
identify the strategically more significant factors for an airline. The contemporary study has tried to look for the following research questions:

(i) What are the various factors affecting the productivity and competitiveness of an airline?

(ii) How are the selected factors related to each other?

(iii) How can these selected factors be classified according to their driving and dependence in the developed model?

To answer the above research questions, contemporary research aims to target the following objectives:

To identify and prioritize the factors affecting the productivity of the airline industry.

To establish the interaction among the factors using interpretive structural modeling with polarity (TISM-P).

To classify the selected factors into four quadrants based on their driving power and dependence using FuzzyMICMAC analysis.

\section{Factors Affecting Productivity of the Airlines Industry}

\section{Export Performance of the Airline Industry in India}

India is the third-largest national aviation market globally and is likely to overtake U.K. in the coming years (IBEF reports, 2020). As per the IBEF reports, foreign investment of up to $49 \%$ is allowed in the airline industry in India. International passengers for Indian airlines have increased to 69 million in 2019 from 65.48 million in 2018 . International passengers constitute nearly $20 \%$ of total passengers, and international freight traffic constituted roughly $60 \%$ of total freight traffic in 2020 . For this reason, its forex earnings and export performance has improved a lot in the past decade. Figure 1 portrays the air transport services' total forex earnings/total income for financial years 1991-1992 to 2019-2020. Air Transport Services includes airlines industry and its associated industries. From the Fig. 1, it can be inferred that the total income and forex earning of the Air Transport Services in India have increased over the years. In this study, the factors affecting the productivity of airline industry in India is only considered. This research aims to look into the export performance of the four Airlines from India:(i) Air India Ltd., (ii) Interglobe Aviation Ltd, (iii) SpiceJet Ltd, and (iv) Go Airlines India Ltd. Table A1 (given in supplementary file) illustrates the financial overview and export performance for the previous decades of the airlines mentioned above.

\section{Productivity Factors of Airline Industry in India}

An extensive literature review was done, and many experts were consulted to identify the factors affecting the productivity of airline industry in India. The identified enablers of operational excellence were examined and discussed in the four brainstorming sessions held with the experts working in the airline industry in India (Air India, SpiceJet, HAL, Indigo). The brainstorming sessions were completed in 42 days, starting from July 2020 to August 2020. The selected 17 factors affecting productivity in the airline industry are explained in Table 1 . Thirty experts of considerable knowledge and experience in the concerned field were selected (experts' profile has been shown in Table A2 given in supplementary file).

\section{Methodology and Application}

The TISM-P approach establishes the interplay among the identified factors and throws light on the relationship among the select factors (Garg \& Sushil, 2021). This approach helps in identifying the most critical factors in the research.
Fig. 1 Trends in Total Income and Forex Earning for all Air Transport Services in India (in Billion INR) ( Source: Developed based on data accessed from CMIE Prowess Database, last accessed on 29th Nov., 2020 at prowessdx.cmie.com)

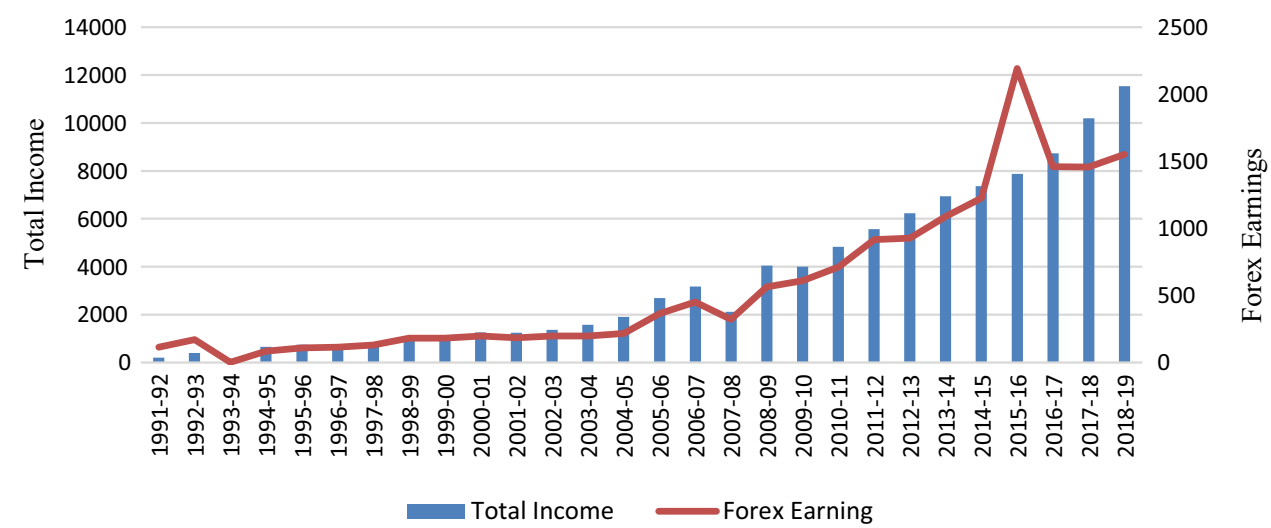


Fuzzy-MICMAC further assists in classifying the factors depending upon their driving and dependence power. The Fuzzy-MICMAC approach would make the analysis more specific.

\section{Total Interpretive Structural Modeling-Polarity (TISM-P)}

TISM is an interpretive and qualitative method that aids in apprehending complex and poorly enunciated problems in a defined and organized form (Thakur, 2020; Dhir et al., 2021). The modified TISM-P is a better approach that incorporates polarity in the established relationships (Sushil, 2018).

\section{Steps Involved in TISM-P Methodology}

Step 1: The present study has identified various factors affecting airlines' productivity through a literature survey and opinions from industry veterans.

Step2: Then, contextual relationships among various factors and outcome factors related to productivity in the airline industry have been examined by brainstorming sessions held with the experts.

Step 3: After that, a reachability matrix with polarity is developed to reflect each factor's influence on the other factor (see Table 2). The ' + ' sign signifies in Table 2 that ' $X$ ' is influencing ' $\mathrm{Y}$ ' positively, and the '-' sign infers that ' $\mathrm{X}$ ' is influencing ' $\mathrm{Y}$ ' negatively. After that, the polarity has been removed from the final reachability table for further calculations (for more details, see Sushil, 2018).

Step 4: After that, the partitioning of the airline industry's productivity factors is done (Refer to Table A3 given in supplementary file). A hierarchical relationship model is constructed, and only significant transitive links are kept.

Step 5: Finally, the developed TISM model with incorporated polarity is checked for conceptual inconsistency, and if required, modifications are done (see Fig. 2).

\section{Fuzzy-MICMAC Analysis}

Fuzzy-MICMAC analysis helps to scrutinize the factors depending upon their driving and dependence powers in the developed model (Singh \& Sushil, 2013). MICMAC analysis classifies the factors into four quadrants based on the binary relationships that have been defined in the reachability matrix. The binary relationship shows the presence or absence, based on 1 and 0 scores, respectively. FuzzyMICMAC analysis aids in explaining the strength of relationships among various factors on $0-1$ scale $(0-$ no, $0.1-$ negligible, 0.3-low, 0.5-medium, 0.7-high, 0.9-very high, 1 -full). Thus, fuzzy numbers describing the probable interactions among all the selected factors make the MICMAC analysis more sensitive. Thus, fuzzy MICMAC would help the decision-makers to interpret the results more precisely. The fuzzy numerical value is levied on the binary direct relationship matrix and transformed into FDRM (shown in Table A4 in supplementary file). For computing the fuzzy indirect relationship matrix, the developed FDRM
Table 2 Reachability matrix with polarity for the productivity of airlines industry

\begin{tabular}{llllllllllllllllll}
\hline Factors & 1 & 2 & 3 & 4 & 5 & 6 & 7 & 8 & 9 & 10 & 11 & 12 & 13 & 14 & 15 & 16 & 17 \\
\hline F1 & 1 & 1 & 1 & 1 & 1 & 1 & 1 & 1 & 1 & 1 & 1 & 1 & 1 & 1 & 1 & 1 & 1 \\
F2 & 0 & 1 & 0 & 1 & 1 & 1 & 1 & 1 & 1 & 1 & 1 & 1 & 1 & 1 & 1 & 1 & 1 \\
F3 & 0 & 0 & 1 & 1 & 1 & 1 & 1 & 1 & 1 & 1 & 1 & 1 & 1 & 1 & 1 & 1 & 1 \\
F4 & 0 & 0 & 0 & 1 & 1 & 0 & 0 & 0 & 1 & 1 & 1 & 1 & 1 & 1 & 1 & 1 & 1 \\
F5 & 0 & 0 & 0 & 0 & 1 & 0 & 0 & 0 & 0 & -1 & 1 & 1 & 1 & 1 & 1 & 1 & 1 \\
F6 & 0 & 0 & 0 & 0 & 1 & 1 & 0 & 0 & 1 & 1 & 1 & 1 & 1 & 1 & 1 & 1 & 1 \\
F7 & 0 & 0 & 0 & 0 & 0 & 0 & 1 & 0 & 1 & 1 & 1 & 1 & 1 & 1 & 1 & 1 & 1 \\
F8 & 0 & 0 & 0 & 0 & 1 & 0 & 0 & 1 & 1 & 1 & 1 & 1 & 1 & 1 & 1 & 1 & 1 \\
F9 & 0 & 0 & 0 & 0 & 0 & 0 & 0 & 0 & 1 & 1 & 1 & 1 & 1 & 1 & 1 & 1 & 1 \\
F10 & 0 & 0 & 0 & 0 & 0 & 0 & 0 & 0 & 0 & 1 & 0 & -1 & -1 & 0 & 1 & 1 & 1 \\
F11 & 0 & 0 & 0 & 0 & 0 & 0 & 0 & 0 & 0 & -1 & 1 & 1 & 1 & 1 & 1 & 1 & 1 \\
F12 & 0 & 0 & 0 & 0 & 0 & 0 & 0 & 0 & 0 & 0 & & 1 & 1 & 0 & 1 & 1 & 1 \\
F13 & 0 & 0 & 0 & 0 & 0 & 0 & 0 & 0 & 0 & 0 & 0 & 1 & 1 & 0 & 1 & 1 & 1 \\
F14 & 0 & 0 & 0 & 0 & 0 & 0 & 0 & 0 & 0 & 0 & 0 & 1 & 1 & 1 & 1 & 1 & 1 \\
F15 & 0 & 0 & 0 & 0 & 0 & 0 & 0 & 0 & 0 & 0 & 0 & 0 & 0 & 0 & 1 & 0 & 1 \\
F16 & 0 & 0 & 0 & 0 & 0 & 0 & 0 & 0 & 0 & 0 & 0 & 0 & 0 & 0 & 0 & 1 & 1 \\
F17 & 0 & 0 & 0 & 0 & 0 & 0 & 0 & 0 & 0 & 0 & 0 & 0 & 0 & 0 & 0 & 0 & 1 \\
\hline
\end{tabular}


Fig. 2 TISM-based model for airline productivity

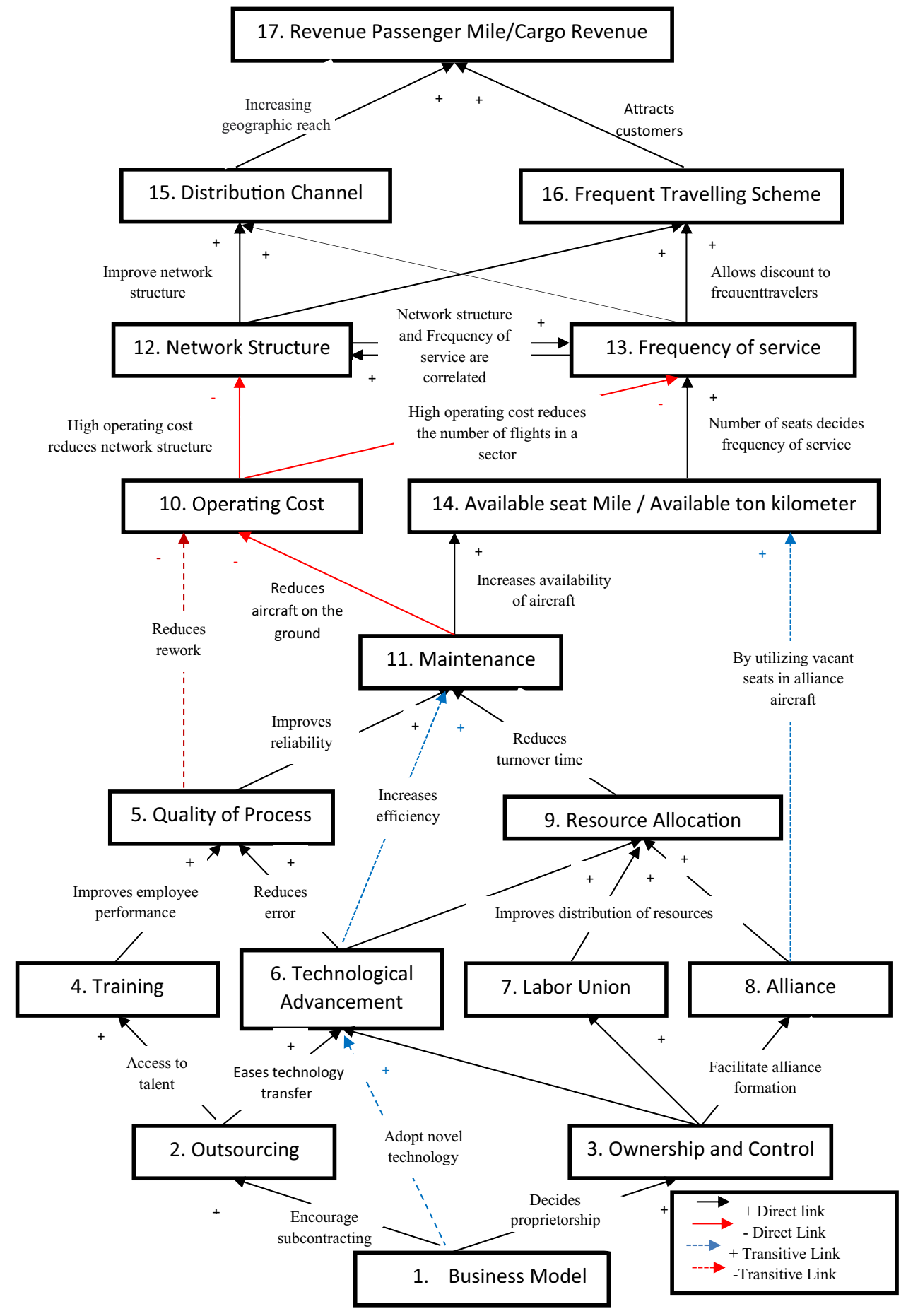

matrix is multiplied repeatedly until all the hierarchy factors' drive and dependence power hierarchy factors' driving and dependence powers get stable. The multiplication of a fuzzy matrix will always result in a fuzzy matrix only (Thakur \& Anbanandam, 2016a, 2016b).

$X * Y=\max \left[\min \left(x_{i k}, y_{k j}\right)\right]$,
After finding the stabilized matrix, the driving and dependence powers for each factor have been computed. Dependence power has been calculated by taking the sum of corresponding row values for each factor, and dependence power has been computed by summing all values in the corresponding column. Factors are arranged following their driving and dependence power, as shown in Table 3.

where, $X=\left[x_{i k}\right], Y=\left[y_{k j}\right], X$ and $Y$ are fuzzy matrices. 
Table 3 Stabilized Fuzzy-MICMAC matrix for factors of productivity of the airline industry

\begin{tabular}{lllllllllllllllllllll}
\hline Factors & 1 & 2 & 3 & 4 & 5 & 6 & 7 & 8 & 9 & 10 & 11 & 12 & 13 & 14 & 15 & 16 & 17 & Driving Power \\
\hline 1 & 1 & 0.9 & 0.9 & 0.9 & 0.9 & 0.9 & 0.9 & 0.9 & 0.9 & 0.9 & 0.9 & 0.9 & 0.9 & 0.9 & 0.9 & 0.9 & 0.9 & 15.4 & \\
2 & 0.5 & 1 & 0.5 & 1 & 0.9 & 0.7 & 0.5 & 0.9 & 0.7 & 0.9 & 0.9 & 0.9 & 0.9 & 0.9 & 0.9 & 0.9 & 0.9 & 13.9 & \\
3 & 0.9 & 0.9 & 1 & 0.9 & 0.9 & 0.9 & 0.9 & 0.9 & 0.9 & 0.9 & 0.9 & 0.9 & 0.9 & 0.9 & 0.9 & 0.9 & 0.9 & 15.4 & \\
4 & 0.5 & 0.5 & 0.5 & 1 & 0.9 & 0.7 & 0.5 & 0.7 & 0.7 & 0.9 & 0.9 & 0.9 & 0.9 & 0.9 & 0.9 & 0.9 & 0.9 & 13.2 & \\
5 & 0.5 & 0.5 & 0.5 & 0.5 & 1 & 0.5 & 0.5 & 0.5 & 0.5 & 1 & 1 & 0.9 & 0.9 & 1 & 0.9 & 0.9 & 0.9 & 12.5 \\
6 & 0.5 & 0.5 & 0.5 & 0.5 & 0.9 & 1 & 0.5 & 0.7 & 0.9 & 0.9 & 0.9 & 0.9 & 0.9 & 0.9 & 0.9 & 0.9 & 0.9 & 13.2 \\
7 & 0.5 & 0.5 & 0.5 & 0.7 & 0.7 & 0.7 & 1 & 0.7 & 0.7 & 0.9 & 0.7 & 0.9 & 0.9 & 0.7 & 0.9 & 0.9 & 0.9 & 12.8 \\
8 & 0.5 & 0.5 & 0.5 & 0.7 & 0.7 & 0.7 & 0.5 & 1 & 0.7 & 0.7 & 0.7 & 0.7 & 0.7 & 0.7 & 0.7 & 0.7 & 0.7 & 11.4 \\
9 & 0.5 & 0.5 & 0.5 & 0.5 & 0.5 & 0.5 & 0.5 & 0.5 & 1 & 0.7 & 0.7 & 0.7 & 0.7 & 0.7 & 0.7 & 0.7 & 0.7 & 10.6 \\
10 & 0.5 & 0.5 & 0.5 & 0.5 & 0.5 & 0.5 & 0.5 & 0.5 & 0.5 & 1 & 0.5 & 0.9 & 0.9 & 0.7 & 0.9 & 0.9 & 0.9 & 11.2 \\
11 & 0.5 & 0.5 & 0.5 & 0.5 & 0.5 & 0.5 & 0.5 & 0.5 & 0.5 & 1 & 1 & 0.9 & 0.9 & 1 & 0.9 & 0.9 & 0.9 & 12 \\
12 & 0.5 & 0.5 & 0.5 & 0.5 & 0.5 & 0.5 & 0.5 & 0.5 & 0.5 & 0.7 & 0.5 & 1 & 0.7 & 0.7 & 0.7 & 0.7 & 0.9 & 10.4 \\
13 & 0.5 & 0.5 & 0.5 & 0.5 & 0.5 & 0.5 & 0.5 & 0.5 & 0.5 & 0.7 & 0.5 & 0.7 & 1 & 0.7 & 0.9 & 0.9 & 0.9 & 10.8 \\
14 & 0.5 & 0.5 & 0.5 & 0.5 & 0.5 & 0.5 & 0.5 & 0.5 & 0.5 & 0.7 & 0.5 & 0.9 & 0.9 & 1 & 0.9 & 0.9 & 0.9 & 11.2 & \\
15 & 0.5 & 0.5 & 0.5 & 0.5 & 0.5 & 0.5 & 0.5 & 0.5 & 0.5 & 0.7 & 0.5 & 0.7 & 0.7 & 0.7 & 1 & 0.9 & 0.9 & 10.6 \\
16 & 0.5 & 0.5 & 0.5 & 0.5 & 0.5 & 0.5 & 0.5 & 0.5 & 0.5 & 0.5 & 0.5 & 0.5 & 0.5 & 0.5 & 0.5 & 1 & 0.9 & 9.4 & &
\end{tabular}

\section{Results and Discussions}

This conceptual model would assist in identifying the factors that need to be focused on to improve airlines' operational excellence. For instance, in our research, outsourcing, training program, alliance, quality of the process, resource allocation is critical drivers that need to be paid special attention to improve the operational excellence of an airline. Figure 3 portrays the seventeen factors on a two-dimensional graph: dependence power and driving power. Fuzzy-MICMAC analysis has categorized these factors into four groups based on polarity of 'Driver power' and 'Dependence' as shown in Fig. 3: Group 1 (autonomous group), Group 2 (dependent group), Group 3 (linkage group), and Group 4 (independent group).

Group I: Weak driving and dependence power: The factors in this cluster are debarred from the developed TISM model, and they are identified as the autonomous group. In this research, no factor appeared in the first quadrant.

Group II: Weak driving and strong dependence: The second quadrant factors have a strong dependence power and less influence on other factors. In the present study, the following factors fell in this quadrant: network structure, frequency of service, available seat mile, distribution channel, frequent traveling scheme, revenue passenger mile. Therefore, the second group factors should be given lesser priority, and airlines' administrators should critically explore the dependence power of the related factors while formulating strategies.
Group III: Strong driving and dependence power: In this research, six factors are having strong driving and dependence power, namely: training program, quality of process, technological advancement, alliance, resource allocation, operating cost, maintenance. The above-stated six factors lie in the middle of the conceptualized model and should be handled with the utmost care while formulating policies.

Group IV: Strong driving and weak dependence power: Group IV: Strong driving and weak dependence power: The following factors are identified as independent variables: business model, outsourcing, ownership and control, and labor union. Airlines' policy-makers should focus primarily on these factors in the first stage, and these factors need to be on top priority while developing strategy.

\section{Utility of the Presented Model}

The present research has developed a conceptualized model for the factors affecting the productivity of airline industry in India. TISM model kept the factors (outsourcing, ownership control, and business model) at the hierarchy's base, and these factors are essential to the airline industry's operational excellence. Revenue passenger mile is our outcome factor and is placed at the top of the developed model. Figure 3 divides the selected factors into four clusters based on their driving and dependence powers obtained from the fuzzy-MICMAC analysis. This clustering creates insights for airline administrators so that they can proactively deal with the above-selected factors. 
Fig. 3 Analysis of driving and dependence power of factors of productivity

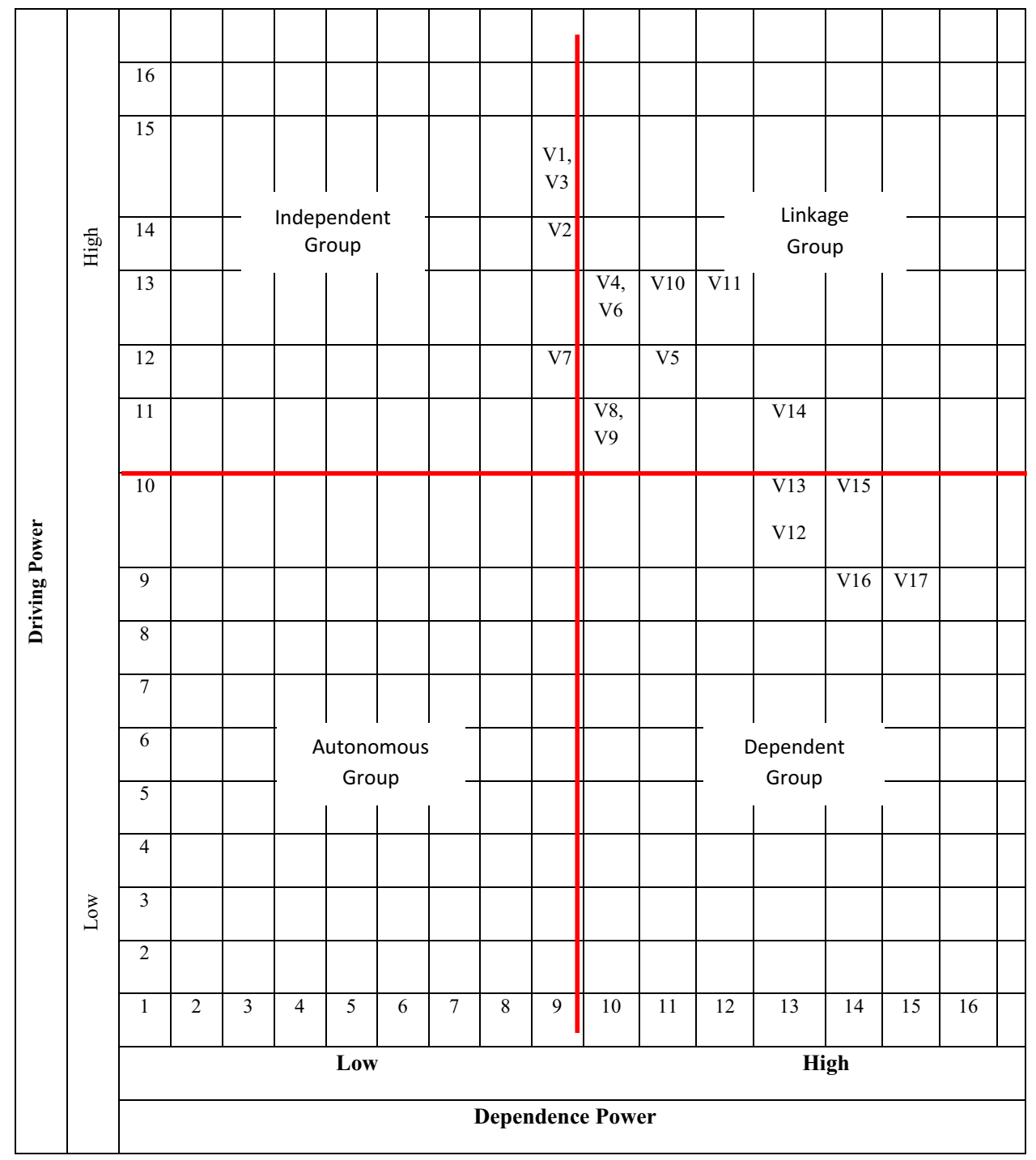

TISM model has placed the factors' Business model' 'Outsourcing', 'Ownership and control', 'Training program', 'Alliance' 'Labor Union', and Technological advancement' at the hierarchy's base, showing that these factors have the highest driving power and are vital for improving the operational performance of airline industry in India. Fuzzy-MICMAC has also validated that these factors are the essential pillars for enhancing an airlines' operational excellence. Sengur and Sengur (2017) and Thakur and Mangla (2019) assert that business model innovation creates the value proposition, including resource allocation, designing employees' training programs, technological development, minimizing operational costs, deciding on the network structure, and many more. Wan et al. (2009) also confirmed in their study that alliance decides the network structure of an airline. Byles (2007) observes that agreements such as "EU-US Open Skies" bring stiff competition to non-members where Virgin Atlantic, United Airlines, British Airways, and American Airlines are allowed to fly between the United States and London's Heathrow airport and vice versa. Chong (2007) studied Singapore Airlines and observed that training plays an essential role in infusing corporate values.

The factors that lie in the middle of the hierarchal model include: 'Quality of process', 'Resource allocation', 'Operating cost', 'Maintenance', 'Available seat mile', 'Network structure', and 'Frequency of service'. Fuzzy-MICMAC analysis has also placed these factors in the third quadrant depicting them as linkage factors. These five factors are having high driving as well as high dependence powers. These are linkage factors that are influencing and being influenced by other factors in the system. Dominic and Jati (2011) examined many quality dimensions in five Asian carrier flag airlines and noticed that the process quality positively impacts airlines' operational excellence. IndiGo has managed to achieve high aircraft utilization by effectively using its resources. May and Barry (2011) proclaim that an airline with a higher number of seat miles 
would earn more revenue per passenger mile. The following factors are placed at the top of the hierarchy in the developed TISM model 'Frequent traveling scheme', 'Distribution channel,' 'Revenue passenger mile'. Fuzzy-MICMAC analysis also confirmed the results from the empirical investigations and classified these factors into the dependent group. While formulating any strategy to improve an airline's operational excellence, these second group factors should be given lesser priority compared to the other factors. The top management should efficiently utilize these input resources and follow a holistic approach to improve the operational excellence of the airline industry in India.

\section{Conclusion}

To gain international market share, airlines should focus on improving their operational excellence. Therefore, the research's primary objective was to identify the factors affecting the airline industry's productivity issues to improve the competitiveness of an airline. The study has identified the interaction among the 17 factors affecting the operational excellence of the airline industry using interpretive structural modeling with polarity (TISM-P). The selected factors are classified into four clusters based on their driving power and dependence using Fuzzy-MICMAC analysis. The study identified that factors identified that business model, ownership and control, training, alliance are the significant factors that need to be focused on to improve the operational excellence of an airline. This research would help top management of the airline industry in formulating the strategy to increase the overall system's efficiency and effectiveness.

Contemporary research has few limitations, and these open up opportunities for the future scope of the study. First, the developed model is built by reviewing select writings and is based upon the inputs given by a limited number of experts; hence biasedness in collecting opinion may be there. Inadequate linkage of drivers of productivity with relevant factors of competitiveness may be a major limitation. One topic of high potential for future research can be deeper analysis of competitiveness dynamics using structured frameworks such as "Competitiveness Assets-Processes-Performance (APP)" (Momaya, 2001) to find options to improve service and export competitiveness. This model could be further validated using the structural equation modeling technique (SEM).

\section{Key Questions Reflecting Applicability in Real Life}

1. What are the various factors affecting the productivity of an airline?

2. How are the selected factors related to each other?
3. How can these selected factors be classified according to their driving and dependence in the developed model?

4. Explore the potentials of airline productivity factors in post-pandemic times.

5. What are the major pandemic challenges ahead of airline productivity, how these challenges can impact service excellence of airline industry?

6. Compare and benchmark the productivity factors of airline industry in India across international counter parts, discuss international competitiveness of airline industry in post-pandemic times.

Supplementary Information The online version contains supplementary material available at https://doi.org/10.1007/s42943-021-00035-7.

Acknowledgements Authors are very thankful to all the anonymous reviewers, who have invested their valuable time for reviewing the work and providing their suggestions. Authors are also thankful to Dr. K. S. Momaya (Editor-in-chief) and Dr. Sourabh D. Kulkarni (Lead Guest Editor) for their inputs to improve the overall quality of the manuscript.

Author Contributions SG: Conceptualization of model, methodology, formal analysis, writing — original draft, writing — review and editing. VT: Conceptualization of model, supervision, review and editing.

Funding Authors further state that there is no funding support has been received to carry out this study.

Availability of data and material Available on request.

\section{Declarations}

Conflict of interest Authors declare that there is no conflict of interest.

\section{References}

Arulraj, D. J., \& Annamalai, T. R. (2020). Firms' financing choices and firm productivity: Evidence from an emerging economy. International Journal of Global Business and Competitiveness, 15, 35-48. https://doi.org/10.1007/s42943-020-00008-2

Barbot, C., Costa, Á., \& Sochirca, E. (2008). Airlines performance in the new market context: A comparative productivity and efficiency analysis. Journal of Air Transport Management, 14(5), 270-274. https://doi.org/10.1016/j.jairtraman.2008.05.003

Chang, Y. H., \& Yeh, C. H. (2004). A new airline safety index. Transportation Research Part b: Methodological, 38(4), 369-383. https://doi.org/10.1016/S0191-2615(03)00047-X

Chiambaretto, P., \& Wassmer, U. (2019). Resource utilization as an internal driver of alliance portfolio evolution: The Qatar Airways case (1993-2010). Long Range Planning, 52(1), 51-71. https:// doi.org/10.1016/j.lrp.2018.02.004

Chong, M. (2007). The role of internal communication and training in infusing corporate values and delivering brand promise: Singapore Airlines' experience. Corporate Reputation Review, 10(3), 201212.https://doi.org/10.1057/palgrave.crr.1550051

Dhir, S., Rajan, R., Ongsakul, V., Owusu, R. A., \& Ahmed, Z. U. (2021). Critical success factors determining performance of cross-border 
acquisition: Evidence from the African telecom market. Thunderbird International Business Review, 63(1), 43-61. https://doi.org/ 10.1002/tie. 22156

Dominic, P. D. D., \& Jati, H. (2011). A comparison of Asian airlines websites quality: Using a non-parametric test. International Journal of Business Innovation and Research, 5(5), 599-623. https://doi.org/ 10.1504/IJBIR.2011.042451

Eller, R. D. A. G., \& Moreira, M. (2014). The main cost-related factors in airlines management. Journal of Transport Literature, 8(1), 8-23. https://doi.org/10.1590/S2238-10312014000100002

Fu, X., Jin, H., Liu, S., Oum, T. H., \& Yan, J. (2019). Exploring network effects of point-to-point networks: An investigation of the spatial patterns of Southwest Airlines' network. Transport Policy, 76, 36-45. https://doi.org/10.1016/j.tranpol.2019.01.004

Garg, S. \& Sushil (2021). Factors of deglobalization: A hierarchical model to explore their interrelations as a conduit to policy. Journal of Policy Modeling., 43(2), 433-447. https://doi.org/10.1016/j.jpolm od.2021.01.001

Gelmez, E., Özceylan, E., Mete, S., \& Durmuşoğlu, A. (2020). An empirical research on lean production awareness: The sample of Gaziantep. International Journal of Global Business and Competitiveness, 15, 10-22. https://doi.org/10.1007/s42943-020-00010-8

Hammer, M. (2004). Deep change: How operational innovation can transform your company. Harvard Business Review, 82(4), 84-93.

Khuong, M. N., \& Uyen, T. M. (2014). The factors affecting vietnam airlines service quality and passenger satisfaction-a mediation analysis of service quality. International Journal of Innovation, Management, and Technology, 5(5), 327. https://doi.org/10.7763/IJIMT.2014.V5. 535

Knorr, A., \& Arndt, A. (2002). Successful Entry Strategies on the Deregulated US Domestic Market-the Case of Southwest Airlines. Universität Bremen.

Lazzarini, S. G. (2007). The impact of membership in competing alliance constellations: Evidence on the operational performance of global airlines. Strategic Management Journal, 28(4), 345-367. https://doi. org/10.1002/smj.587

May, M., \& Barry, M. (2011). The Effects of Airline Alliances on Airfares, Revenue Passenger Miles, and Available Seat Utilization (Doctoral dissertation, Boston College. Carroll School of Management).

Momaya, K. (2001). International competitiveness: Evaluation and enhancement. Hindustan Publishing Corporation.

Murty, A. V. N. K., \& T., Goel, N. . (2013). Performance Analysis of Airline Services (A critical study of Global Scenario). International Journal of Engineering and Management Research, 3(6), 37-46.

Oum, T. H., Waters, W. G., \& Yu, C. (1999). A survey of productivity and efficiency measurement in rail transport. Journal of Transport Economics and Policy, 33(1), 9-42.

Pekuri, A., Haapasalo, H., \& Herrala, M. (2011). Productivity and performance management-managerial practices in the Construction Industry. International Journal of Performance Measurement, 1(1), $39-58$.

Prowess CMIE. (2020). https: //prowe ssdx.cmie.com/kommo n/bin/ sr.php?kall=wdisp req\&reqid $=37914 \& \mathrm{msg}=2$. Retrieved 29 th Sep 2020.

Ratanakomut, S., \& Kitcharoen, N. (2013). A Study of Factors That Affecting Service Quality of Passenger Service Department in Airlines (AIRASIA, Thailand). Innovative Journal of Business and Management, 2(1).

Sengur, Y., \& Sengur, F. K. (2017). Airlines define their business models: A content analysis. World Review of Intermodal Transportation Research, 6(2), 141-154.

Singh, A. K., \& Sushil. (2013). Modeling enablers of TQM to improve airline performance. International Journal of Productivity and
Performance Management, 62(3), 250-275. https://doi.org/10.1108/ 17410401311309177

Sriram, C., \& Haghani, A. (2003). An optimization model for aircraft maintenance scheduling and re-assignment. Transportation Research Part A: Policy and Practice, 37(1), 29-48. https://doi.org/ 10.1016/S0965-8564(02)00004-6

Srivastava, G. K., \& Chaurasia, P. (2015). Problems and prospects of civil aviation industry in India after new economic policy. Anusandhanika, 7(2), 126.

Suhardjanto, D., \& Ajibroto, N. (2017). Ownership structure and financial performance: An empirical study of listed airlines industry in Asia and Australia. Review of Integrative Business and Economics Research, 6(1), 121-130.

Sushil \& Garg, S. (2019). Internationalization of Tata Motors: strategic analysis using flowing stream strategy process. International Journal of Global Business and Competitiveness, 14(1), 54-70. https:// doi.org/10.1007/s42943-019-00006-Z

Sushil (2018). Incorporating polarity of relationships in ISM and TISM for theory building in information and organization management. International Journal of Information Management, 43, 38-51. https://doi.org/10.1016/j.ijinfomgt.2018.06.003

Swidan, H., \& Merkert, R. (2019). The relative effect of operational hedging on airline operating costs. Transport Policy, 80, 70-77. https:// doi.org/10.1016/j.tranpol.2019.05.001

Thakur, V. (2021). Framework for PESTEL dimensions of sustainable healthcare waste management: Learnings from COVID-19 outbreak. Journal of Cleaner Production, 287, 125562. https://doi.org/10. 1016/j.jclepro.2020.125562

Thakur, V., \& Anbanandam, R. (2016a). Shift from product supply chain management to services supply chain management: a review. International Journal of Services and Operations Management, 23(3), 316-346. https://doi.org/10.1504/IJSOM.2016.074817

Thakur, V., \& Anbanandam, R. (2016b). Healthcare waste management: an interpretive structural modelling approach. International Journal of Health Care Quality Assurance, 29(5), 559-581. https://doi.org/ 10.1108/IJHCQA-02-2016-0010

Thakur, V., \& Mangla, S. K. (2019). Change management for sustainability: Evaluating the role of human, operational and technological factors in leading Indian firms in home appliances sector. Journal of Cleaner Production, 213, 847-862. https://doi.org/10.1016/j.jclep ro.2018.12.201

Treacy, M., \& Wiersema, F. (1995). The discipline of market leaders: Choose your customers, narrow your focus, dominate your market. Perseus Books.

Vasigh, B., \& Fleming, K. (2005). A total factor productivity-based structure for tactical cluster assessment: Empirical investigation in the airline industry. Journal of Air Transportation, 10(1), 3.

Wan, X., Zou, L., \& Dresner, M. (2009). Assessing the price effects of airline alliances on parallel routes. Transportation Research Part E: Logistics and Transportation Review, 45(4), 627-641.https://doi.org/ 10.1016/j.tre.2009.01.003

Wang, W., Tang, O., \& Huo, J. (2018). Dynamic capacity allocation for airlines with the multi-channel distribution. Journal of Air Transport Management, 69, 173-181.https://doi.org/10.1016/j.jairtraman. 2018.02.006

Wei, W., \& Hansen, M. (2005). Impact of aircraft size and seat availability on airlines' demand and market share in duopoly markets. Transportation Research Part E: Logistics and Transportation Review, 41(4), 315-327. https://doi.org/10.1016/j.tre.2004.06.002

Wei, W., \& Hansen, M. (2007). Airlines' competition in aircraft size and service frequency in duopoly markets. Transportation Research Part E: Logistics and Transportation Review, 43(4), 409-424. https://doi.org/10.1016/j.tre.2006.01.002 